\title{
Analysis of the Relationship Between Inflation and Economic Growth
}

\author{
Weina Qin \\ Collaborative Innovation Center for Security and \\ Development of Western Frontier China \\ Sichuan University \\ Chengdu, China
}

\author{
Qinglong Wang \\ School of Economics \\ Sichuan University \\ Chengdu, China
}

\begin{abstract}
In recent years, with the commodity prices boosting, people are more concerning high price level and it also makes the decision maker a dilemma how to face the inflation trade-off with economic growth in the short run. Meanwhile, hot money flow into many countries and bulk commodity prices of international has also risen, which is doubt that get the inflation worse. But in view to the change of ten years, a lot of country's GDP (gross domestic product) has still a steady growth rate. This paper mainly analyses the authenticity and accuracy of above statement on the ground of the model and date factors that analyses the relatively between mild inflation, normal inflation and hyperinflation and economic growth. It held the point that mild inflation that may lubricate the wheel of labor market, lead the invest market better can promote the economic growth; normal inflation can reduce the unemployment and therefore rise the level of output. While the hyperinflation, taking people a great hazard, leading the economic to low efficient, is bad to economic growth.
\end{abstract}

\section{Keywords—rising prices; inflation; economic growth}

\section{INTRODUCTION}

In 2008, the United States triggered a financial crisis and spread all over the world. In order to mitigate the impact of the financial crisis, countries have introduced a series of monetary and fiscal policies to make the economy grow steadily. However, the continuation of rising prices, consumer expectations for rising prices, and the impact of rising oil prices have increased inflation in various countries. This makes policy makers unprepared, faced with short-term trade-offs of inflation and unemployment, and at the expense of how much GDP reduces inflation, which is bound to have a very negative impact on the economic development of countries. In view of this, it is necessary to analyze the correlation between inflation and economic growth.

"Table I" shows the average annual economic growth rate of China and other four emerging economic powers and six developed countries such as the United States from 1992 to 2016, as well as the annual inflation rate expressed by CPI and GDP deflator respectively. As you can see, China under the height of the average annual growth rate of $10.5 \%$ growth, the inflation rate is far lower than the rate of economic growth, the United States, Germany, Britain, France and Italy, the average annual economic growth rate and inflation rate is flat, Japan at a low economic growth rate of $0.9 \%$, low inflation rate is $0.1 \%$, while Brazil's average annual growth rate of $3.2 \%$, less than half of India, the rate of inflation and its phase is similar, but Russia's average annual growth rate is only $1.0 \%$ but the average inflation rate above $20 \%$. The data partially show that moderate inflation and general inflation can lubricate the economy and keep growth steady, while hyperinflation may keep growth low.

TABLE I. AVERAGE ANNUAL INFLATION RATE AND AVERAGE ANNUAL ECONOMIC GROWTH RATE OF 10 COUNTRIES INCLUDING CHINA AND THE UNITED STATES FROM 1992 TO 2016

\begin{tabular}{|l|l|l|l|}
\hline country & $\begin{array}{c}\text { average annual } \\
\text { economic growth } \\
\text { rate }\end{array}$ & $\begin{array}{c}\text { the annual } \\
\text { CPI increase } \\
\text { rate }\end{array}$ & $\begin{array}{c}\text { the annual } \\
\text { GDP deflator } \\
\text { increase rate }\end{array}$ \\
\hline China & 10.5 & 4.9 & 5.6 \\
\hline USA & 2.7 & 2.5 & 2.1 \\
\hline Japan & 0.9 & 0.1 & -0.7 \\
\hline Germany & 1.3 & 1.9 & 1.3 \\
\hline UK & 2.5 & 2.1 & 2.3 \\
\hline France & 1.6 & 1.6 & 1.6 \\
\hline Italy & 1.0 & 2.8 & 2.8 \\
\hline India & 6.9 & 7.4 & 6.7 \\
\hline Brazil & 3.2 & 7.0 & 8.4 \\
\hline Russia & 1.0 & 21.5 & 22.3 \\
\hline
\end{tabular}

a. Source: the above data are from the world bank database. The average annual CPI growth rate and average annual GDP growth rate in Brazil and Russia are 1996-2016 averages.

\section{LITERATURE REVIEW}

As for the relationship between inflation and economic growth, there has been no consensus in academic circles. The classical school believed that inflation had no effect on real economic variables such as employment and output, so the currency was neutral. Keynesianism holds that inflation affects real economic variables such as investment, consumption and output, so money is not neutral. At present, there are three theoretical views on the impact of inflation and economic growth in foreign economic circles. The first is that inflation promotes economic growth (Tobin, 1965, Tayloz, 1982); The second view is that inflation reduces the efficiency of the price mechanism, which is detrimental to economic growth (Jose De Gregorio, 1993).The third view holds that nominal variables and real variables do not influence each other, that is, inflation does not affect economic growth (Keynes, 1933).As for China's specific 
reality, different scholars have drawn different conclusions about the relationship between the two. Liu ling and leyun(2005) using 1978-2003 annual data analysis, think that China's money supply in the long term expansion can promote economic growth, while inflation hinder economic growth, economic growth will spur the money supply expansion, and the money supply in the short-term expansion can stimulate economic growth, economic growth rate will increase in the stimulus money supply growth rate, also can stimulate the rate of inflation to rise. Wei Rongrong, Cui Chao (2011), using the data from 2006-2010 degrees, has nothing to do with inflation, economic growth in the long run inflation is increasing promote economic growth and, in turn, inflation and harm economic growth.

\section{THE THEORETICAL MODEL OF THE RELATIONSHIP BETWEEN INFLATION AND ECONOMIC GROWTH}

Should policy be positive or negative? This is a question policymakers have been groping for. Although monetary and fiscal policies have been in place for a long time, the idea that governments should use these tools to try to stabilize the economy has only emerged in recent years. Monetary and fiscal policy can have a powerful effect on aggregate demand and hence on inflation and unemployment. Okun's law tells us that unemployment is negatively correlated with economic growth, so changes in aggregate demand can have an impact on inflation and economic growth. Therefore, it is necessary for the government to create a certain amount of inflation in order to stabilize economic growth.

\section{A. Supply and Demand Model}

"Fig. 1" shows the short - and long-term equilibrium between price level and output after the increase of total demand. The horizontal axis is income or output, and the vertical axis is price level. The graph shows the relationship between the rise in prices and the fluctuation in output caused by the economy from the short term to the long term when aggregate demand increases. We can see from the picture in the short run, aggregate demand after moving, because of price stickiness assumptions, the same price level, the equilibrium in SRAS from $\mathrm{E}_{0}$ and $\mathrm{E}_{1}$, output increased from $\mathrm{Y}$ to $\mathrm{Y}_{2}$, a prosperous economy. In the medium and long term, the assumption of price stickiness is broken, price level rises, equilibrium moves in $\mathrm{AS}$, first passing $\mathrm{E}_{1}$ and then $E_{2}$, and output decreases from $Y$ first to $Y_{2}$ and then to $Y_{1}$. Although the economy was booming and then declining, the economy as a whole was producing more. In the long term, due to assume that markets clear, the prices continue to rise, balanced in LRAS mobile, pass first $\mathrm{E}_{0}, \mathrm{E}_{1}$ and $\mathrm{E}_{2}$, finally to $E_{3}$, output from $Y$ to $Y_{2}$ before they are reduced to $\mathrm{Y}_{1}$, finally back, experienced prosperity and decline in the economy of two process, and finally, back to the natural level. Therefore, in the short term, prices are sticky and there is no inflation. Therefore, according to the Keynesian hypothesis, the correlation between inflation and economic growth cannot be seen. In the medium and long term, inflation is positively correlated with economic growth. In the long run, according to the classical assumption, inflation has no effect on economic growth.

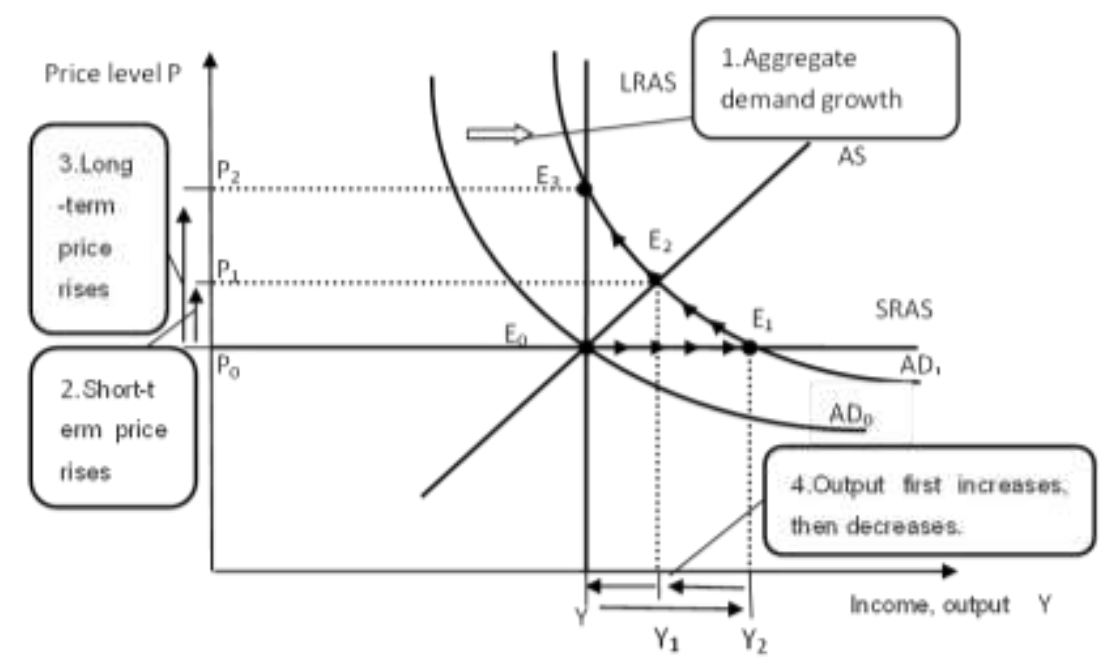

Fig. 1. The short - and long-term equilibrium between price level and output after the increase of total demand.

\section{B. Phillips Curve}

In the figure above, we have obtained the relationship between price level and output. To make the relationship between inflation and economic growth more clear, we use the Philips curve.

In "Fig. 2", the relationship between inflation and real GDP is drawn in the short and long term. The horizontal axis is the actual output and the vertical axis is the inflation rate.
Source: based on books on macroeconomics by N Gregory Manklw nd Robert j. Gordon In the short term, the Philips curve tilts to the top right, and inflation is positively correlated with real GDP. Over the long term, the Philips curve is a vertical line, inflation has no relation to real GDP, and output is a natural level.

We can see from the picture, in the short term, the expected price for $\mathrm{P}$, when prices rose from $\mathrm{P}$ to $\mathrm{P}_{1}$, at first people haven't adjust their expectations of price, equilibrium in $\mathrm{SP}_{0}$ in $\mathrm{E}_{1}, \mathrm{toE}_{0}$, output increased from $\mathrm{Y}$ to $\mathrm{Y}_{1}$, the economic comes prosperity. Over time, people begin to 
realize that rise in price levels, to revise their price expectations, expected prices to $\mathrm{P}_{1}$, it makes up the shortterm Philips curve, then reduce output, output, reduced from $Y_{1}$ to $Y$,equilibrium from $E_{2}$ to $E_{1}$, and output to return to nature. In the long term, people expected the price also for $\mathrm{P}_{1}$, when prices rose from $\mathrm{P}$ to $\mathrm{P}_{1}$, output increased from $\mathrm{Y}$ to $\mathrm{Y}_{1}$ first, and then reduced to $\mathrm{Y}$, balanced from $\mathrm{E}_{0}$ first to $\mathrm{E}_{1}$ and $E_{2}$, the economy has experienced prosperity and decline process of two, in the end, return to natural level.

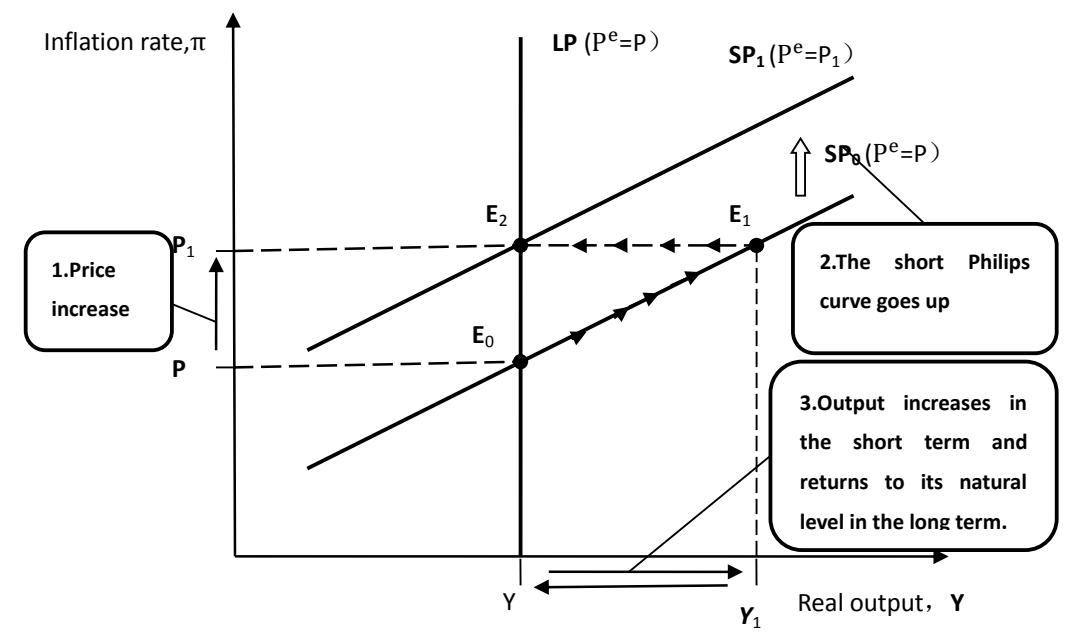

Fig. 2. The relationship between inflation and real GDP is drawn in the short and long term.

\section{The Quantitative Relationship Between Inflation and Economic Growth}

The modern phillips curve consists of expected inflation, cyclical unemployment and supply shocks,

$$
\pi=\pi \mathrm{e}-\beta(\mathrm{u}-\mathrm{un})+v
$$

Type of $\pi$ for inflation, $\pi$ e for expected inflation, $u$ as the unemployment rate, the un as the natural rate of unemployment, u-un as a cyclical unemployment, $\beta$ to measure the degree of reaction parameters of inflation to cyclical unemployment, $v$ for supply shocks. The above equation shows the negative relation between periodic unemployment and inflation. Okun's law derives the relationship between unemployment and output. The following equation is a form of okun's law, namely:

$$
(\bar{a}) \quad(\mathrm{Y}-\bar{Y})=-\beta(\mathrm{u}-\mathrm{un})
$$

Type of $\mathrm{Y}$ as the output, as $\overline{\mathrm{Y}}_{\text {the natural level of output, }}$ $\underline{1}$ as $\bar{a}$ the output for sensitive index of cyclical unemployment, on illustrates the output the deviation of their natural level and is negatively related to the deviation of the natural rate of unemployment. So higher unemployment leads to a decrease, lower unemployment leads to an increase.

We can also get it from the above two equations.

$$
\pi=\pi \mathrm{e}+\left(\frac{1}{a}\right) \quad(\mathrm{Y}-\bar{Y})+v
$$

Source: drawn from a textbook on macroeconomics by Robert j. Gordon

It can be seen from the formula that the positive relationship between inflation and output is that inflation goes up, output goes up, inflation goes down, and output goes down.

\section{CORRELATION ANALYSIS OF INFLATION AND ECONOMIC GROWTH}

\section{A. The Relationship Between Moderate Inflation and Economic Growth}

Economists believe that a weak inflation on economic growth is a good thing, because it can "wheel lubrication Labor market" effect, make better investment market operation, thereby promoting effect on economic growth.

Support for moderate inflation starts with the idea that nominal wage cuts are a rare reality, that companies are unwilling to cut nominal wages and that workers are unwilling to accept them. In a world of zero inflation, a $2 \%$ pay cut under the actual value is equal to 5\% inflation of $3 \%$ pay rise, and workers think that the $2 \%$ pay cut like a kind of damage to them, and a $3 \%$ pay rise after all is a raise. The findings suggest that a certain level of inflation may make the labor market work better. Supply and demand for different types of labor are always changing, and sometimes an increase in supply or a decrease in demand results in a decline in the real wages of a group of workers. If nominal wages can't cut, then the only way to cut wages is that inflation is complete the task, so mild inflation can plays a role of lubricating the wheel of the Labor market, it can avoid result in higher unemployment, the economy on track.

Irving Fisher pointed out that nominal interest rates are the sum of real interest rates and inflation. Investment is based on the level of interest rates as a reference standard. In 
financial markets and investment released most of the nominal interest rate market, this will make many myopic investors in accordance with the nominal interest rate investment, but others have as high as investors will be investment according to the actual interest rate, therefore, in a world of zero real interest rates, as people will not investment. With $2 \%$ inflation, a nominal interest rate of $2 \%$ would send many short-sighted investors into the investment market. Moderate inflation may make investment markets work better. At times when the economy is in a recession, the government does not want to raise real interest rates but also wants to raise nominal interest rates to stimulate investment. Therefore, moderate inflation can promote economic growth and make the economy run smoothly.

"Fig. 3" shows China's annual inflation rate and economic growth rate from 1992 to 2016. The horizontal axis represents the year and the vertical axis represents the percentage of growth.

Through comparative analysis, China's inflation and economic growth show the following basic characteristics:

Economic growth rate rises, lagging behind a period of rising inflation, the inflation peak lags behind economic growth and economic growth fell back, the rate of inflation lag period, the rate of inflation and economic growth at the same time back to the bottom.

The economic growth rate and inflation rate trend are basically similar, but the inflation rate fluctuation is larger than the economic growth rate, more like the enlarged economic growth rate.

As can be seen from the above data, inflation rate and economic growth rate show a certain correlation.

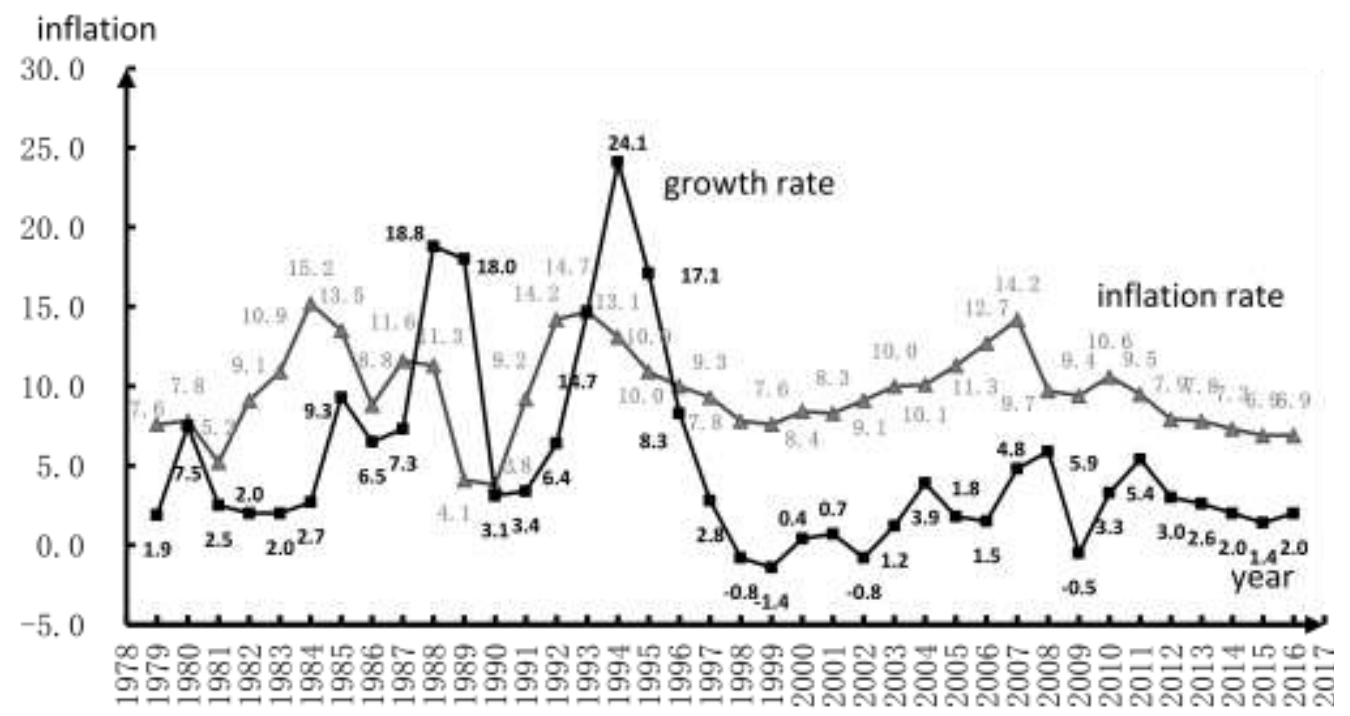

Fig. 3. China's annual inflation rate and economic growth rate from 1992 to 2016.

\section{B. The Relationship Between General Inflation and Economic Growth}

Due to many variables in the model is assumed, in the model the conclusion we not enough accurate, in order to exactly it is concluded that the relationship between the variables, we from the model to the reality that the relationship between data analysis. Using nearly half a
Source: data for 2011-2016 are from China's statistical yearnook and data for other years are from the World Bank database. century of data from more than 100 countries, the correlation between inflation and economic growth has been established.

Due to inflation and unemployment is one measure of this economic situation is very important, so, economists often through the Philips curve of the lens to observe macroeconomic development, "Fig. 4" shows the United States since 1960 the history of inflation and unemployment. 


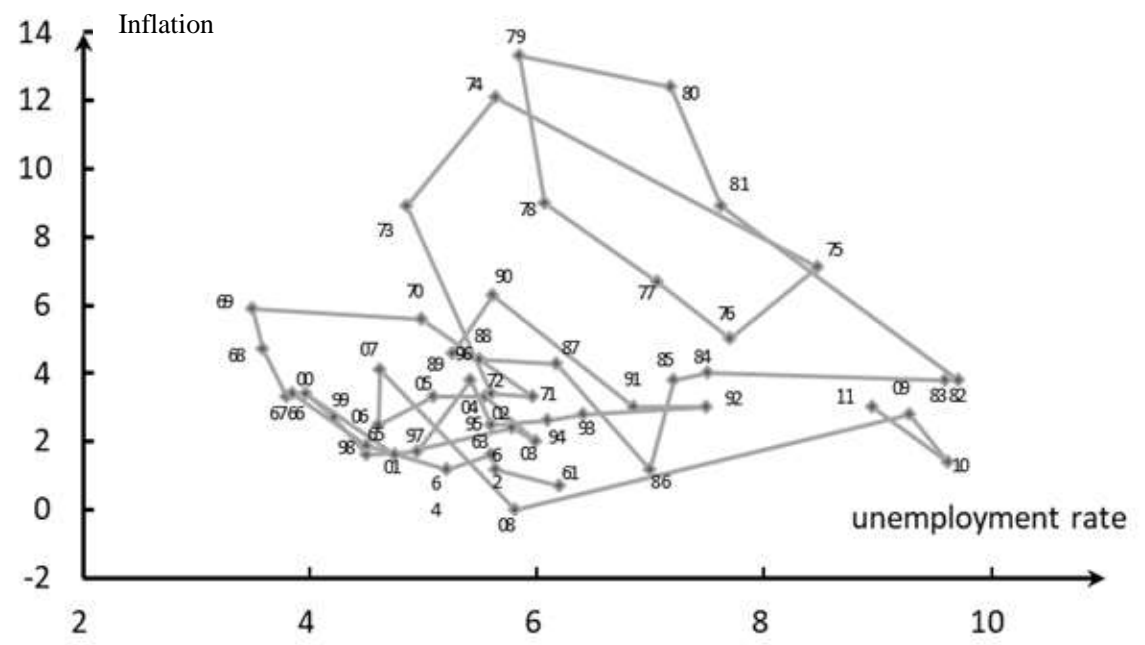

Fig. 4. The inflation and unemployment in the United States since 1960.

The graph shows that in the 1960s, policy makers reduced unemployment and accelerated economic growth at the expense of higher inflation in the short term. Rising inflation, however, make people expected future prices will rise, thus raising the expectations of inflation, thus further is rising inflation, as inflation rose to $6 \%$ in year 1968, 1969 or so.

In the $1970 \mathrm{~s}$ is a period of economic turmoil, the decision makers 10 years trying to lower the legacy of inflation in the $1960 \mathrm{~s}$, as can be seen from the graph curve is spiral shape of this century, the inflation falling unemployment to rise, decline after inflation, rising unemployment, caused by the government planned the recessions, but the recession's impact on inflation, not offset before this prosperous dilatability influence, to the same as ten years ago, the unemployment rate in 1972 and 3\% higher inflation.

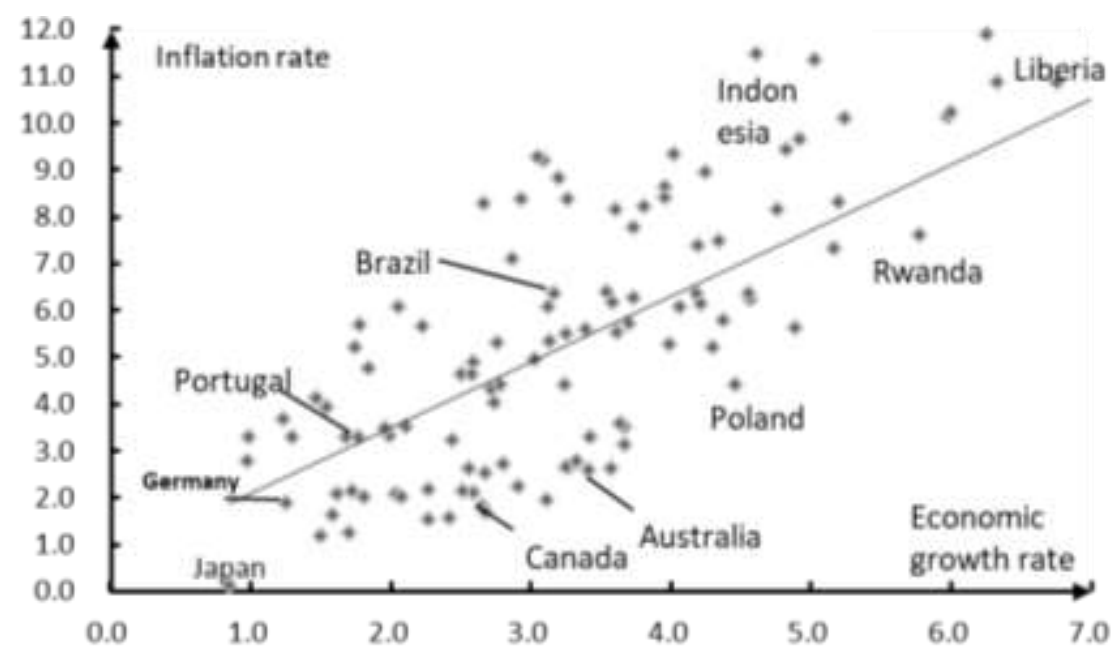

Fig. 5. The relationship between inflation rates and economic growth rates in 109 countries.

In the 1980 s, policy makers tried to reduce high inflation and pursued some monetary policies. In 1982 and 1983, the unemployment rate reached its highest level in 40 years. High unemployment, combined with falling oil prices, has pushed inflation from around $10 \%$ to around $3 \%$, a period of low growth.

Compared with the previous 30 years, the economy was relatively calm in the 1990s and early 2000s, with both unemployment and inflation in an ideal state and balanced growth. By 2008 America's unemployment rate had risen from around $6 \%$ to around $10 \%$ as a result of the financial crisis, while inflation was roughly flat in the 1990s.

The correlation between inflation rate and economic growth rate can be examined in different countries. "Fig. 5" shows the relationship between inflation rates and economic growth rates in 109 countries in 1992-2016.

\footnotetext{
Fig. 5. The relationship between inflation rates and economic growth rates in 109 countries.
} 
As can be seen from this scatter diagram, the inflation rate of a country is closely related to the economic growth rate. Countries with high inflation rates tend to have high growth rates, such as Japan's at $0.1 \%$ and Japan's at $0.8 \%$. Countries with low inflation tend to have low growth rates. Liberia's economy grew 6.3 percent and inflation 10.9 percent.

In many countries, the inflation rate is similar to the economic growth rate. For example, Australia's economic growth rate is $3.4 \%$ and the inflation rate is $2.6 \%$.Canada's economy grew by 2.7 percent and inflation by 1.8 percent. And inflation is concentrated in countries such as Canada and nearby Brazil, where inflation is concentrated between $1 \%$ and $6 \%$.The trend lines are evenly distributed across 109 countries, from which it is clear that inflation and economic growth are positively correlated, as shown by the trend line.

\section{The Relationship Between Hyperinflation and Economic Growth}

Hyperinflation brings many costs to the economy and causes many consequences, which make the economy into a state of inefficiency. The costs of hyperinflation include both expected costs and unexpected costs, which will bring great harm to the society.

The first cost of hyperinflation is the distortion of the inflation tax on the amount of money people hold. According to the fisher effect, higher inflation leads to higher nominal interest rates, which in turn reduce the real monetary balance. If people feel that they have less money, they will run to the bank more frequently to withdraw money, which will cause their shoes to wear out more quickly. This cost is called sole cost. Hyperinflation causes businesses to change their prices every day and restaurants to print new menus every day, which can be costly. Many of the provisions of the tax code do not take into account the impact of inflation, and the occurrence of hyperinflation has no intention of increasing taxes on individuals and businesses. If increase individual income tax burden, capital gains tax is mishandled, this can cause very big cost. The existence of hyperinflation, make people's life is very inconvenient, because money is our economic transactions, measured by the scale length has been change, this will make people get into a state of misplaced, so bring a lot of cost on the economy.

The effect of unanticipated hyperinflation is more harmful than any cost of stable and predictable inflation. Creditors by ex-ante real interest rates, borrowing from the debtor but vicious inflation, the debtor creditors, the money value that will create wealth from creditors to debtors, harm the interests of creditors. Because the pension is deferred income, so workers in essence is to provide loans to businesses and workers to provide labor services to companies when they are young, but older after got all the compensation, if there is a vicious inflation, so workers like any creditors, the depreciation of the compensation, so as to be hurt.

Hyperinflation bring a lot of cost, these costs enough to offset the benefits of hyperinflation can lead to chaos, commodity prices are flocking to snap up goods, from the black market for stable currencies, this would cause a recession, so vicious inflation and economic growth showed a negative correlation.

\section{CONCLUSION}

Through the above model, data, and text analysis, we can see the inflation and economic growth has certain relevance, mild inflation lubricates the labor market, indirect stimulation of labor supply, to promote economic growth. Higher nominal interest rates lubricate capital markets by increasing savers' wealth and thus consumption and ultimately economic growth. From okun's law and Philips equation of the relation between the general inflation and economic growth, it is concluded that the general inflation and economic growth present positive correlation relationship, through 109 countries scatterplot shows can clearly see the relationship; Hyperinflation increased people's sole cost, menu cost and inconvenient, people will be increased with the increase of prices of super-fast focus from work to let their own wealth preservation, labor efficiency decline will slow down economic growth.

For people to live and work in peace and contentment, steady economic growth, governments should better decisions inflation and economic growth in the short-term trade-off, letting the coexistence of inflation and economic growth, but avoiding the happening of hyperinflation, making the economy into a low efficiency, which is great inconvenience to people's life. At the same time, it is necessary to control the speed of money issuance and people's expectations of inflation, as well as the impact of supply to turn general inflation into hyperinflation.

\section{REFERENCES}

[1] N. Gregory Mankiw. Macroeconomics.[M]. Renmin university of China press, 6th edition.

[2] Robert j. Gordon. Macroeconomics.[M]. Northeast university of finance and economics press, 10th edition.

[3] Zeng fan hui, An empirical test of the relationship between China's money supply, inflation and economic growth.[J]. Financial research (2015).

[4] Liu yun . Money supply, inflation and China's economic growth -empirical analysis based on co-integration [J]. Statistical research,2005,(3): 14-18.

[5] Luo wen bao. The relationship between inflation and economic growth since India's economic reform [J] South Asia research quarterly 2017, 2nd issue. 